\title{
Christian pedagogy, education and teaching
}

\section{Introductory remarks}

The question which confronts one at the outset is: What is the nature and content of that christian pedagogy, education, teaching and type of school for which Calvinists in South Africa have struggled in the past, and in fact are still struggling for, even today?

One cannot answer this question without mentioning the name of Prof Dr J Chris coetzee, for many years professor in Pedagogy, later on Dean of the Faculty of Education and still later Rector of the $\mathrm{PU}$ for $\mathrm{CHE}$. His ex-students fill a variety of po= sitions in every sector of teaching in South Afri= ca and they still make immeasurable contributions to the spirit in which education takes place in this country. In spite of the fact that the greater majority of educational scientists attached to South African universities and other institutes of higher education practise the so-called pheno= menological method of educational science there are still Christian educationists working through= out the country. They all work on the basic prin= ciples as expounded by Prof coetzee which - it should be admitted - were influenced by the Philos= ophy of the Cosmonomic Idea of Dooyeweerd and the Philosophy of the Idea of Creation by Stoker.

Coetzee can be regarded as one of the few educa= tionists who concerned himself with all the various pedagogical disciplines and who succeeded in publishing standard text books (standard in his 
own time) on the philosophy and history of educa= tion, didactics, empirical and comparative educa= tion.

In the discussion in the following paragraphs of some trends in pedagogy and education the reader should always bear in mind that the point of de= parture and reference is a Calvinistic world and life view. This point of view has as its basis the belief in the sovereignty of God, the compre= hensive nature of Biblical authority and the uni= versality of the calling to proclaim the Kingdom of God. The Word of God and the calling to extend the Kingdom of God apply to every walk of life, and for that reason it is also applicable to every aspect of teaching and education.

\section{Christian pedagogy}

\subsection{View of life and its relevance for pedagogy}

According to Proverbs 4:23 the "heart" of man is the "fountain of life". A person's view of life is an expression of his "heart". His "heart" (direction in life) and his "life" (his actions) are inseperable, since a humar being is a single entity. He is always involved in his every activ= ity as a complete being. Religion (which can be described as an all-embracing disposition of man's "heart", in contrast with divine worship which can be defined as cult) is based on man's heart, and tnerefore it determines the "airection" of the science ( $i$ c education) which is practised by any educationist. Religion supplies a certain "colour, tint or shade" to the scientific study in question.

Pedagogy may be regarded as a report of scientific reflections and $f$ indings regarding education. Pedagogy then, being a human activity, like all human activities, is based on or rooted in the specific religion (or convictions of "heart") of the educational scientist. Religious neutrality therefore does not really exist in fact: "neutral= ity" in science ( $c$ education) must for this reason be regarded as a specific point of view, a basic choice made by the scientist, a choice 
determined by his religion. The fact that we find so many different approaches to pedagogy must therefore be ascribed to the various religious convictions held by educational scientists, and this variety of religious convictions can again be explained by the presence of sin in the world: man has become unfaithful to God and has shown a con= tinuous tendency to accept religious substitu+es for the true belief in God which is the correct religious conviction of heart.

The true Christian however has no alternative but to practise Christian science (j. c education).

\subsection{To practise Christian pedagogy does not mean scientific isolation}

To be a Christian scientist does not mean to be isolated from others who are of a different opin= ion. It does not mean a breakdown in communica= tion. On the contrary, it may be stated that he who has determined the religion behind a specific science (in this case, pedagogy), he who has eluc= idated the religious presuppositions of the science he practises can communicate effectively with other scientists because he understands his own science. Moreover, it must be noted that the Christian scientist acknowledges the providential actions of God also in the works of non-Christians (cf Matthew 5:44): it is therefore also possible for the nonChristian scientist to form conceptions of outic reality, but since he fails to recognise the clari= fying light of God's specific revelation (Holy Scripture) he tends to falsify and misunderstand this reality (Rom 1: 20, 21, 22, 25). The Christ= ian philosopher (and specific scientist) cannot however accept outic reality as it is conceived by the non-believer. It has to be isolated from its false religious context and purified of the false elements caused in it by such a false religion be= fore it can be placed in the correct perspective supplied by the word of God. The Christian philos= opher rejects accommodation and syncretism, but that does not imply that he has to suffer scienti= fic isolation. He takes note of other education= ists at work and studies their work, but always uses the word of God as his guide line, belance 
and standard.

\subsection{Science and the idea of science}

All knowledge, and therefore also scientific know= ledge, is in part determined by a specific relig= ious idea as regards its basic form and general trends. The nature of this idea, again, is deter= mined by the subject of knowledge, the action of knowing, the method and the aim(s) of science.

Science is a typically human activity; to see man as the subject of knowledge (anthropology) is a prerequisite in determining the idea of science. so-called "neutral" sclence is based on a mechan= istic conception of man (scientist), since it supposes man to be equal to the sum of all his parts, and divides belief (view of life) and knowledge (the art of knowing) into seperate com= partments of human existence. On the other hand, it is clear that a rationalistic study of an ob= ject of science can be traced back to an anthrop= ology which is based on the recognition of the autonomy of human reason.

In the Calvinistic idea or conception of science one can also discern a particular view of man or anthropology: it is held that man was created in the image of God, that he is totally committed to serve God, that he is a personal unity because of his religious ego, that he is a broken being since the fall of man in Paradise. This Fall has the effect that man falter in his various relation= ships: he discards the authority of God in his own life, he is inclined to abuse nature, all his ac= tions and deeds (including his practice of educa= tion and pedagogy) are of an ambivalent nature, that is, they either serve God and his fellow-man or they do not. Lastly, man is bound by laws (natural laws and norms or standards), but being a sinner man seeks his own salvation outside of these laws.

The nature of a scientist's conception of science is also partly determined by the scientist's view of reality. He who believes that rcality can only bo explained as an internal activity, as a personal 


\begin{abstract}
expression, in other words, employs an internalcosmic view of reality, is prepared to accept knowable reality as the only source of scientific knowledge. Such a point of view cannot but lead to the absolution of some or other aspect of real= ity (so-called cosmological absolutionisms, - isms like realism, phenomism, materialism etc).

In contrast, the christian scientist accepts also the Bible as a source of knowledge of truth and of reality. It is the aim of all science to ascert= ain what is true and real, and what is not. He who believes in the truth of Holy scripture cannot discard it in his guest for truth and reality even if he cannot prove the truth of the Bible it= self. After all, ignoring the Holy scripture in one's search for scientific truth is not necessar= ily tantamount to proving the Bible false or un= truthful. Although the Scriptures do not pretend to present scientific facts, they present facts regarding God, man and reality which cannot be ig= nored in any scientific investigation. Without the clarifying light of the Holy scripture all reality remains dark; without the unfailing per= spective supplied in (by) the Holy Scripture the sinful eye of the scientific observer remains out of focus (Ps 36:10, 119:105). The light of the Holy Bible must not be viewed as something added to the reality which is the object of science - it merely enables the scientist to see that object of his investigation truthfully and correctly.

Also the method of science can never be neutral, since it is also determined by religious convic= tions. Therefore it follows that the phenomenolog= ical method of practising science is determined by a mechanistic-ontic apriori (vide the anthropology of Kant) and a dualistic-ontic apriori (vide the Thomistic cosmology). And he who endeavours to explain the learning process of human beings anal= ogous to that of animals is operating from a naturalistically orientated point of departure. The phenomenistic as well as the naturalistic approach does not take the revealed word of God (the Holy Bible) into account. In opposition to such an approach, the christian does not merely try to describe reality but also takes pains to
\end{abstract}


explain reality. He attempts to clarify relation= ships, to evaluate and verify findings and results of his research. The humanistic approach of science claims as one of its principles that the aim of science is to serve man and mankind. For this reason the scientist practises science solely for the sake of science, pedagogy for the sake of pedagogy. The Christian scientist, however, views the practice of science as a way of fulfilling the wish and calling of God, as a means by which sin can be combated, as a means by which all men may strive for the advent of Christ.

\subsection{Christian pedagogy}

It must be stated at the outset that Christian pedagogy is no amalgam or mixture of science on the one hand and divine worship on the other. It is, however, religious service to God, for all things were created by Him, and all things exist through $\mathrm{Him}$ and for $\mathrm{Him}$ (Rom $11: 36$ ), science in general as well as the science of pedagogy. Cristian pedagogy is therefore replying to a Divine calling. The all-embracing Calling of man is to serve and to love God with all his powers (Deut 6:5, Mart 12:29) and his fellow-man as he would love himself (Matthew 22:39). Coupled to this, man is also called to preserve and to sub= due the cosmos which God has created. This in= volves exploiting the cosmos and to bring it to fruition. This calling also presents the educat= ionist with his task as scientist: in full re= sponsibility to God, out of love for his fellowman and himself, and in full awareness of his calling with regard to nature and culture it is required of him to practise and to teach pedagogy as a science.

The Christian educationist is aware of the follow= ing -

* that he is the bearer of a calling from God

* that he is responsible to God for all his actions

* that he has limitations, being a human being created by God

* that he (and other people, pupils, teachers, 
other educationists and students of pedagogy) as well as the cosmos has a destination (deter= mined by God) which should be reached

* that man and cosmos were (and are still) contam= inated by sin

* that Jesus Christ is not only Redeemer and Saviour, but also the Re-creator of the entire cosmos, including man

* that Christ, to whom was given all authority in heaven and on earth (Matthew 28:18), is also King of the pedagogy

* that he, being a Christian, is called and in fact compelled to commence and sustain battle against $\sin$ (including his own sinful disposi= tion) in all walks of life, including the field of pedagogy

* that he should always endeavour to change that which was spoiled by sin so that it may the bet= ter serve God in future.

Christian pedagogy can therefore be described as a pedagogy which endeavours to understand, explain, evaluate and describe education in terms of the Holy scripture. It is a type of pedagogy which wishes to also verify its results by that which can be known loutic reality as well as the revealed reality) by means of scientific methods (which can also be verified outically as well as by means of the Holy Scripture). The practice of Christian pedagogy is inevitable if the educationist is a Christian, it is unavoidable, what can be termed a radical "must". Like Martin Luther the Christian educationist has to say: "Here I stand; I cannot otherwise". Standing in fact, by order of God, and standing in responsibility to God, the Christ= ian educationist is free, because he kneels in his love for God.

\subsection{Biblical perspectives relevant for pedagogy}

* All things were created by God, and all things find their eventual destination in God. Be= cause of this the Christian educationist is aware that all phenomena in reality are not self-sufficient, and also that these phenomena are subject to the law of God. For this reason he will refrain from absolutising any aspect of 
the cosmos, like man (humanism), or nature (na= turalism), or facts (positivism) or the pheno= menon which is investigated (phenomenism).

* The created cosmos is composed of a radical diversity or variety of things. The Christian educationist will refrain from ignoring this diversity of created things. Consequently he will acknowledge the radical difference between man and animal regarding the process of learn= ing.

* On the other hand, it must be recognized that God created an underlying coherence in the aforementioned diversity of things. The Christ= ian educationist acknowledges this. He knows, for example, that belief and knowledge are two seperate and irreducible entities, but at the same time he acknowledges their coherence in order not to be tempted to isolate them in a dualistic fashion as Kantian educationists are wont to do.

* The Holy Bible supplies so much information about man that a Christian anthropology can be easily formulated. We learn, for example, from the Bible that man (be he educationist, pupil, etc) is not sufficient unto himself: he is the image of God, free in all his actions, respons= ible to God only for what he does, he bears a calling to create culture (like practising $r a=$ dagogy), a calling to serve God comprehensively, to serve his fellow-man and himself dutifully, a calling to honour God, a calling to be a coworker of God in the task of recreating and renewing the cosmos, including the child, which should be recognised as part of the cosmos.

* The Holy Bible also reveals to man (i $c$ the educationist) his all-embracing calling to serve God in all things, to love himself and his fellow-man and to bring the cosmos to full fruition. The Christian educationist is there= fore aware of the fact that he is practising pedagogy in honour of God, with the aim of expanding the Kingdom of God, of serving himself and his fellow-man. 
* The Holy Bible similarly reveals the univelsal corruption brought about by sin in this world. Therefore, the believing educationist has no illusions about the results of attempts to in= vestigate any object or phenomenon only with his powers of his (sinful) reason and, conse= quently, he will also know that the "evidence" given by the phenomenon (object of study, which has also fallen under the curse of sin) cannot be anything but false and incomplete.

* Fortunately, though, the Holy Bible also reveals the fact that the cosmos was re-created by the redemption of Christ. The Christian education= ist will therefore be aware of the impossibili= ty of conquering evil (in the cosmos, $i$ e in nature and consequently also in the nature of man) solely by oneself. He will know that the final victory over all evil is guaranteed by the redemption of christ. The light of the Holy Scripture will enable him to recognise evil when he encounters it, and as co-worker of God he will always pitch battle against un Biblical views of man, cosmos and science (in= cluding the aims, contents and methods of science).

\section{Christion education}

\subsection{What is education and teaching?}

Educating and teaching are actions performed by two or more people at a time. They are therefore termed inter-human actions. Therefore, an anthro= pology or view of man is a basic or determining factor in any theory or definition of education and.teaching. And, what is more, the reply to the question: Who or what is man? will be determined by the religious convictions of the person who is questioned.

The naturalist (who simply regards man as a biosocial organism) will view education and teaching as a process in which the correct milieu is supplied for the growth and development $\mathrm{ff}$ the organism (child) according to its pre-determined natural 
character. Pedagogy then becomes nothing more or less than pedagogical phychology which studies the various stadia or phases of growth and development in order to manipulate the environment of educa= tion in such a way that it will be congruent with the phases of maturity.

In this way each individual educationist will for= mulate his own definition or description of educa= tion - from his own point of view, or anthropology. Each human being has such a point of view, a view of life, which is determined in the first instance by his "allignment of heart". Since man is by nature inclined to form his own idols, and since his view of life is integrally and radically found= ed on his belief in such an idol (in other words, all his deeds and actions are based on, and deter= mined by, such a view of life) his philosophy of education will also be determined by his view of life. Anyone who can be called a radical Christ= ian (and all true Christians should be able to be called that) cannot otherwise but hold a Christian philosophy of education and teaching. As christ= ian educationists we do not search for truth and clarity about Christian education and teaching be $=$ cause it is required by law to do so, but because we cannot otherwise than do so.

The inseperable bond between one's religion and one's view of life makes it possible to divide all kinds of teaching and education into two groups, viz humanistic or cosmocentric education and teaching on the one hand and Christian (theocen= tric) education and teaching on the other. The former always absolutizes some aspect of man or cosmos (universe), and consequently that education is characterised by personalization - some or other aspect of humanity is over-emphasized. Education is never without a nucleus of religious commitments or convictions. The insistence by Christians on Christian education and teaching is therefore not something which is forced upon educationists or teachers, but it is simply the logical thing that should take place in any Christian community.

Using our Christian (religious) convictions as 
point of departure, we wish to stress the fact that teaching and education should not be under= stood as one of the following:

* the development of the child's personality

* the guidance of the child to moral maturity

* the fostering of responsibility in the child

* an attempt to convert the pupil to a particular belief

* an attempt to achieve the pupil's social adapt= ation, or

* an attempt to change the pupil into a useful citizen.

All these ideals (held by miscellaneous teachers) are not acceptible, because they are basically hu= manistic, they tend to see man as the centre of all things, and consequently they falsify and dis= tort the true meaning of man's life. These views of the aim of teaching and education leads to the glorification of man, and eventually also to the downfall and subsequent destruction of man. As Christian educationists and teachers we have to look for a circumscription or defenition of educa= tion which has God at its centre or nucleus, and the word of God as its guide-line. The basis for such a definition can fortunately be found in the basic or major calling which man has received from God.

In general terms we can state that education is an act (not a process) between two or among more people: on the one hand the teacher/educationist and on the other the pupil. The former deliberate= ly - and by virtue of his vocation - directs his educational actions to his pupil/student in order to equip the latter, to help and guide him to accept his own vocation in life responsibly and voluntarily. The pupil, on the other hand (being a minor in various ways) requires assistance, aid, advise and guidance from the adult ( $i \mathrm{c}$ teacher) so that he may - as a responsible human being. - apply himself to his vocation in this world. The act of education is not characterised by persuasion and force. (He who is forced to do good does no good.) The act of education must therefore comply with 
certain norms or standards in order to be true and correct education.

The question which is now posed before us is: What must be regarded as man's vocation? In other words, what does he live for? If the act of edu= cating has as its aim to help and guide the pupil to accept his vocation in life it is of vital importance to decide and determine what that voca= tion is. The answer to this question is again determined by the religious convictions of the particular teacher in question. As Christian edu= cationists and teachers we have to (and cannot do otherwise) answer as follows: man has only one all-embracing - vocation: he must love the Lord his God with all his heart, with all his soul, all his mind, and he must love his neighbour as him= self. Added to this, he is called to subdue the earth and rule over it. This is his primary cal= ling in life, the fountainhead of all other cal= lings, the basis of the entire range of his activ= ities as a person. In the Christian school this will be the predominating factor regarding the to= tal educational undertaking of the school: the system of education; the view held of man (teacher and pupil), the act and method of teaching, the subject matter, the aims of education and so on.

Before we proceed to a brief discussion of the above-mentioned elements or aspects of teaching. it is necessary to define the concepts education and teaching from a Christian point of view.

Christian education is a definite, purposeful, truthorientated act in which an adult (teacher) attempts, because he loves God ard is aware of his responsibility with regard to the universe, to help, guide, persuade and shape the minor (pupil) to accept his own vocation or calling in life voluntarily, to help the pupil to realize that he has to serve God with and during his whole life, that he has to proclaim the Kingdom of God in every walk of life, that he has to serve his neighbour, and that he has to exploit the universe in order to bring it to full fruition. Teaching again is the act through which specific knowledge and skill(s) are offered to the pupil by the 
teacher. This act of teaching is conducted in a scientific manner so that the pupil may be assis ted and led to become a fully equipped and con= scientious executive of the task for which he $h=0$ been called.

Christion teaching is that act of teaching in which all the various components (teacher, subject matter, the act of teaching, method, pupil and environ= ment) are characterised by Christian principles and whish are aimed at equipping the pupil in a manner that is scientifically sound. It is therefore an act primarily conceived to help and guide the pupil to become a dutiful executive of the vocation he has received from God.

Teaching - it is plain to see - forms an important and integral part of the total act known as educa= tion, and consequently teaching and education will be treated as a single entity in the following dis= cussion.

\section{Christian teaching}

Man was instructed by God to subject the earth and rule over it (Gen 1:28); the first man was called upon to name all the animals (Gen 2:19 and 20). Before he could do this, however, he required knowledge of the animals and he had to undertake a study of them. Teaching can for this reason be regarded as the direct result of an instruction by God. Moreover, the earth which man was/is to sub= due also belongs to God, and also everything in or on it (cf Ps 24). Man has to act responsibly to= wards it or with it, since it belongs to God. In all his deeds with regard to the earth man should acknowledge God: the doors must be opened so that the Lord God may enter. Sadly, though, this uni= verse which belongs to God fell into possession of Satan as a result of the fall of man in Paradise. To Christ however was given all power in heaven and on earth, his empire is total, all-ambracing, and as such radically opposed to the empire built by satan. Christ combats all evil. Being a $\mathrm{ci}=$ tizen of the Kingdom of Christ, the christian (Christian teacher) is called upon to take up 
arms against Satan and all evil, to proclaim the royalty and sovereignty of Christ over the entire universe. This he can do, for the redemption of Christ is universal; not only human souls were re= deemed. No, on the contrary. He came to this world to redeem the universe, this world. He who prays: "Thy Kingdom come" should - as a "co-worker" of God (1 Cor 3:9) claim the entire universe in the name of God. To be "neutral" when one is teaching (or doing anything else, for that matter) is to betray the Kirigdom of God. The Christian has no other option; pacifism is an attitude which shows no backbone. Our Leader, Jesus Christ, calls on us to take up arms, to do battle. The peace which He brings, is peace with God - never is it peace with Satan and his empire of evil. There can be no "neutral" or midway position: either one ( $i$ c the teacher) admits himself to be a soldier in the army of Christ, or one is against Him and his whole Kingdom (Matthew 12:30). "Neu= trality" amounts to an attitude of opposition to Christ - it opposes the coming of His Kingdom, it rejects the authority of the word of God and denies the sovereignty of God in all spheres of life.

It now seems the appropriate thing to do - in view of what has just been said - to give an exposition of the system of education, teacher and pupil, sub= ject material, act of teaching, teaching method and the aim of teaching from a christian point of view.

\section{The system of education}

A system of education will - among other thirigs reveal the following characteristics:

5.1 The parent who is a Christian must $r \geq$ reassur= ed that the spirit of the school to which he sends his children will be in line with his own (Christian) view of life because

* if it is not, he runs the risk that his child will be adversely influenced;

* most parents in this country undertook (at 
the christening ceremony of their

child(ren)) that they would instruct their child or children in the doctrines of their church, or otherwise see to it that they are instructed according to their pledge at the baptismal font.

Parent participation in education at school (which is in fact demanded by Act 39 of 1967) is therefore in line with Christian opinion.

5.2 Guarantees should be given that those who (are to) teach at Christian schools have re= ceived or are receiving Christian training as teachers. They should be selected on the basis of their belief, and consequently have been taught Christian science, including the Christian science of education.

5.3 Government, as legislator and law-enforcing power, must take an interest in the education which its future citizens are receiving. Government has to control the degree to which its subjects are to be educated in order to maintain a pre-established standard of civil= ization, it has to ensure that sound state and national principles are adopted by schools in order to avoid conflict between the inter= est of school and state. As a servant of God government must ensure that Christian virtues receive proper attention in schools, and that corruption of morals does not take place in any way. Government should also provide all educational facilities from taxes (since edu= cation is one of the national interests of the country). Inspection is carried out to ensure that matters over which the state bears jurisdiction receive the proper care and attention. Government may never (in ac= cordance with the Christian principle of noncontravention) be guilty of state absolutism. State schools run entirely by government can only be tolerated in cases where parents fail to do their duty with respect to the education of their children.

5.4 A Christian government should not tolerate the 


\begin{abstract}
compulsion of the conscience of any of its subjects; freedom of belief should be guaran= teed. Those who entertain a non-Christian be= lief should feel reassured about this, espec= ially with regard to the spirit of education in the country in question. Unlimited free= dom can however not be accepted by the govern= ment: nobody can be allowed to impede the pro= gress of Christianity or to destroy the morals of a people of a country. The fact that a Christian government has a calling to adhere to in responsibility to God makes sure of this.
\end{abstract}

6. The teacher and the pupil (anthropology: view of man)

One of the keystones of Christian education is the Christian view of man.

The teacher can only understand and execute his task in life once he properly understands and knows who and what man is. Sound communication be= tween teacher and pupil is possible only if such communication is based on a sound anthropology. An anthropology which is not clear may have the effect of impeding understanding of each other and communicating with each other. The efficient teaching in school of all subject matter requires a clear view of man as starting point. In the pre= sent time of specialization in certain subjects it seems of especial importance that scientists (and, for that matter, teachers) do not lose sight of the unity of man. A specific view of man can be regarded as the basis of all educational activi= ties. Present times seem to be marked by mechanism, automatism, industrialism, massalisation and tech= nology - endangering the humanity of man to such an extent that a clear anthropology has become indispensible to the educationist and teacher.

Rationalistic and deistic views of man held in the 18 th century (cf I Kant) resulted (among other things) in the so-called "neutral" education. The naturalistic anthropology of the following century (cf S Freud) described man as primarily composed of biological factors and as such he is closely akin to animals. The teacher who, in line with 
this last conception of man, regards man as an ex= tension of the world of animals will in his act of teaching his pupils perform like a trainer of cir= cus animals. The present day negation of principles and norms or standards in teaching and education is based on the existensialistic anthropology of the 20 th century in which man is seen as a being who creates freedom in his own life.

Opposed to all these (humanistic - man=centred) anthropologies we put forward the Christian anthrop= ology which is no less than a vitally important key= stone of Christian education and teaching.

\section{Contents of education}

Also subject content is no "neutral" affair. The naturalist regards the natural sciences as of para= mount importance whereas the idealist will concen= trate his efforts on the humanities, etc.

The teacher who, regardless of the subject matter, intends explaining a specific content only in terms of itself, from the inside (internal-cosmologically) accepts such content as the only true reality. This obviously leads to the absolutization of some or other aspect of reality or cosmos. As Christians however we are convinced that the Bible - although it does not present any scientific facts - is the source of knowledge of God, man and the reality on which every (school) subject is based. The teacher who assumes that he can present his subject without the illuminative perspective of scripture does not only make himself guilty of disregarding the word revelation of God (cf Ps 36:10, 119:105, Prov 1:7) but also ignores the fact of man's fall into sin, and consequently he believes that his cerebral powers were not at all affected by that fall. This amounts to an over-estimation of man's power of reason (rationalism). Those individuals who accuse others who accept Biblical truths in their act of teaching of being confused and misled by unproven decisions of faith or belief, forget that they themselves reject Biblical truths and revelations on the same grounds of unproven decisions of be= lief: they have not proved the Bible to be untrue 
or non-relevant in their teaching. "Christian teaching" should not be mistaken for the addition of a Christian "element" to common place educa= tion - on the contrary, the perspectives supplied by scripture allows us to view reality (in this case, education) in its true perspective. He who switches on an electric light does not add any= thing to the objects on the table at which he wants to look.

In no (school) subject can one do without the re= vealing light of Scripture: it reveals to us the true character, purpose and aim of everything. Not only Religious Instruction, but indeed all subjects are concerned with the religious convictions of one's heart. The fall of man was a total act; the call to take up arms against evil is equally so. Christian education is working for the advent and proclamation of the Kingdom of God.

\section{Method of educating}

Also the method one uses in educating pupils is determined by religion; didactics therefore is also fundamental labour. The didactics of Herbart is in line with his theory of the various stages in which subject matter is presented. He who tends to see man as an extension of the animal kingdom will use training techniques in stead of correct pedagogical and didactical methods. The existensialistic world and life which forms the basis of the phenomenologic method of education emphasizes leadership and the free choice of the pupil while simultaneously dis= regarding equipping the pupil.

Christian didactics shows the following character= istics:

* It does promote indoctrination of concepts since it realizes that man is responsible to God for all his deeds.

* It avoids intellectualism: knowledge for the sake of knowledge.

* It does not satisfy itself with a mere repeti= tion of facts. It seeks to provide guidance to the pupil. 
* It exhibits the belief, hope and love of the educationist.

* It leads the child to accept the Divine God and apply himself to His service.

* It is marked by a radical avoidance of all forms of humanism, including the convictions of Freud and Herbart.

* It acknowledges the unity of the human ego.

* It does not strive for knowledge which leads to egoism, but seeks for knowledge which enhances the glory of the kingdom of God.

* It is not only concerned with the mental powers of the pupil, but also with his emotions and volition.

\section{The aim of ectucation}

The aim of education is the main determining fac= tor in the entire act of educating. The teacher whose sole aim is acquiring knowledge is an intel= lectualist, and one who only aims at the shaping of the pupil's personality in his act of teaching is a humanist. The Christian teacher knows the great commandment: to love God with all your heart, with all your soul, with all your mind and your neighbour as yourself. It is for this reason that there is, and can be, only one aim in education: know= ledge and skill should only serve God and one's neighbour, they are means by which one can work towards the advent of the Kingdom of God. The eventual aim of all teaching is therefore the guiding and equipping of the pupil to conscious and voluntary acceptance and the execution of his vocation on earth.

Thought in the present times is so much endowed with absurdities that even the "death of God" is sometimes proclaimed. But the Christian knows that when the "death" of God is announced all rea= son obviously disintegrates. Teachers who teach knowledge merely for the sake of knowledge, facts for the sake of facts, who do not recognise any aim apart from the factual speeds up the feeling of futility which has in our days crept into so many hearts. Universities and colleges which per= sist in teaching "neutral" science and the school 
which persists with soulless "neutral" teachirg contributes to the feeling that there is no God at work in this world. "Neutral" teaching contributes to the feeling that God has been launched away from the present world to transcosmic distances. Super= ficial emphasis on facts without accompanying in= tensive research into the underlying principles on which these facts are based eventually develops in= to secularism - a point of view which implies that God has no function and meaning for things in the present world and in the pupil's life.

In contrast, the Christian teacher realizes that the teaching of all subjects is devoted to tne service of God. In these times, marked by secular= ism, technology, industrialism and rationalism the gospel of Jesus Christ should remain the focal point of economy, science and technique.

Our own times call for a radical Christian approach to life. God should not be regarded as an "expla= nation" for that which has not yet been explained by science. He must not become the solver of riddles of life, a "filler-up of holes" (in the words of Bouhoeffer), because it follows naturally that God has to withdraw and eventually retire in the face of science which supplies all the answers in the long run: as science develops, solutions will be found for the thus far unsolvable riddles of life, and the upshot will be that God becomes superfluous! It is to avoid this that the christ= ian acknowledges the authority of God in all walks of life, also in our scientific successes and achievements. He should not only be acknowledged and sought in times of crisis as the solver of mis= teries.

A school which is a Christian school only during the Religious Instruction periods causes schizo= phrenia in its pupils, a schizophrenia which will avenge itself in the long run - perhaps in the nearest future, even - causing the death of the souls of our people.

Christian teachers are avocated to be loyal witnes= ses and messengers of Him who sent them to their respective duties, so that their message may 
resound in the conscience of their pupils, now as well as in the distant future.

\section{0. "National education"}

10.1 Lows pertaining to the "national" aspect, and the implication of this legislation

Section 2(I)(b) of the Education act of 1967 stip= ulates that education in South Africa should have a national character, and section 2 (I) (c) of the same act stipulates that the home language (Afri= kaans or English) should be the medium of instruc= tion.

The fact that the act specifically states that the abovementioned national character should be implem= ented in "broad" outlines is a clear indication that the act does not imply any domination or in= doctrination by any particular section of the popul= ation. What is more, the fact that only Afrikaans and English are mentioned in the act indicates that no stipulations were made for other population groups in the educational policy for white South Africans. But, again, the fact the Afrikaans and English are mentioned signifies a recognition of the differences in the national characteristics and aspirations of the two groups. These characteris= tics and aspirations - it is implied - are to be reckoned with in the execution of the educational policy for white South Africans.

Once these stipulations in the act are seen against this background, there can be no doubt that the chief aim of the act is to foster patriotism and love for this country in our schools. Teaching in our schools should be aimed at a deliberate foster= ing of loyalty to South Africa, at promoting the idea of "South Africa first", of pride in one's own, in the good things which have come forth and have taken place in this country. Pupils must learn to love and to make use of these things out of free and intrinsic conviction. National assets should be safeguarded and defended. The pupil must be led to the conviction that he is co-responsible for our national assets. Especially in our own times in 
which young people adopt a so-called "outsider attitude" towards their national and cultural heritage it becomes all the more important to fos= ter this feeling of responsibility. Young people should be so much inspired by education that they will feel themselves involved in all the affairs of this country and its people.

All national groups in this country should be led to the point at which they will co-operate to develope South Africa without running the risk of losing the individual national characteristics of the various groups.

\subsection{Broad outline of "national education"}

\subsubsection{National education takes national identity} into consideration

National idiosyncrasy is something which is achieved over a long span of time, and more likely than not, it is achieved through tears, blood and sweat. Simply ignoring it cannot amount to the destruction of a nation's peculiarities and characteristics. This idiosyncrasy has such a dynamic nature that it forces one to take note of it.

National identity can be most clearly discerned in a people's language, style of life, relations with other nations and population groups, form of govern= ment and religion. This identity must be reckoned with in an educational policy - in conjunction with specific norms which will be indicated in a follow= ing paragraph.

\subsubsection{Home-Zonguage instruction}

One of the most important things that binds a nation together is the native language: it is the only means by which national character can be communicated among a specific people. Small wonder then that home-language instruction is a basic feature of any national policy for education. This implies, among other things, that a people's cultural heritage is for a considerable part achieved in and by such a people's own language. By using their language a people can build up their cultural heritage. 


\subsubsection{Acknowledgement of responsibility towards one's cultural heritage}

National education implies that the young people of a nation should be led to acknowledge their responsibility towards their own country. National education is an appeal to the youth of a nation to exploit and to promote their own culture (which includes economy, customs, order of state, language, art, science, etc) entlusiastically and with inspi= ration. In the South African situation this boils down to the demand that the young people of each national group be inspired to contribute to the wel= fare of the communal homeland, with, of course the conservation of their own national character (which in any case fits into the broad national character). All this of course should also be done in the inter= est of the Kingdom of God.

National education also implies that the political and cultural history of each specific national group should be taught to its children, and also to pro= ceed from this initial stage in the teaching of his= tory to international history. Intra- as well as extra-mural activities should be conceived and plan= ned to equip the pupil to fulfill his duties as citizen in the national as well as the international spheres. Leadership should be discovered, cultivat= ed and fostered with a view to the greater enhance= ment of national and international interests.

\subsubsection{National unity}

National education must be directed at the unity of the young people of a nation. This unity must be based on an intrinsic awareness of belonging toge= ther, and awareness which must be religiously justi= fied, in our case on the grounds of Christian con= victions. Truth must ever remain the basis of it. Within the limits of truth a variety of nations must be regarded as an asset, as something good. Unity of a people does not imply uniformity, and cultural diversity need not be a barrier to communal unity. Anything based on untruths and which threaten national unity must be opposed. 


\subsubsection{Acceptance of authority}

National education also implies fostering a sound concept of authority in order to prevent national unity from being disrupted by anarchy. That does not mean that all criticism is barred, and that un= critical parrotry is suggested. Pupils should at all times be influenced in a pedagogically-correct manner to accept sound standards by which to judge all manifestations of authority. To oppose (be= cause of Christian scruples) unacceptable authority is perfectly legitimate. If however a person who bears authority does not usurp totalitarian powers, and acknowledges the laws of God, it must be insis= ted that all his subordinates show complete obed= ience to him (Rom 13:1-7, John 19:11, Acts 4:19).

\subsubsection{Promoting the national ideal}

In the last instance it must be stressed that national ideals should only be promoted and en= hanced under guidance of Christian belief. By this we mean that:

* all national activities should be subjected to the standards and principles found in the Holy Word of God in order to ensure that nationalism does not deteriorate into disguised chauvenism;

* organizations of (and for) young people should lead the young people to leadership and adherence to sound authority, and that such organizations should be based on the Holy word of God;

* young people should be guided and shaped to an awareness of their responsibility to other nations and national groups within the borders of the country, and also of their (international) vocation to proclaim the Kingdom of God to the ends of earth;

* national identity should always be put to the service of God and one's neighbour;

* young people should be guided and shaped to be eager supporters of a Christian attitude, nation= ally as well as internationally.

Basically, national education boils down to a cal= ling to: 
* bind the nation into a firm unit;

* preserve and enhance national identity;

* construct sound internal relations as well as relations with other nations;

* maintain the freedom and the culture of the nation;

* conceive and shape a Christian keystone on which all the abovementioned things depend: national ideals should never be allowed to supersede Christian ideals; Christian convic= tions should at all times guide national ideals.

One should guard against the tendency to elevate (on principle) things from the past to become sacrosanct. Paul Kruger's thesis that one should build the future on only that which is sound and honourable in the past can be regarded as an ex= pression of Christian philosophy. Anton Rupert entertained the same idea when he expressed the dictum that the past should not become a sofa on which to rest, but that it should rather be re= garded as a launching pad for the future.

The past should never - on principle - be elevated to the status of being a standard, it should never be absolutized or over-estimated. Such a view of the past will be tantamount to traditionalism, and traditionalism can be likened to a stagnant pond which can easily become a cess-pool. The past should always be evaluated in the light of Holy Scripture, and only when it has passed this test may it serve as a corner stone for the future. Sound nationalism is bound in a certain way to tradition without elevating tradition to norm and principle. The Christian principle can be sum= marised as follows: to retain from the past that which is good and sound because it can stand the test of the word of God, and not necessarily be= cause it is tradition or old.

Sound conservatism as well as progressiveness have a role to play in the construction of a national identity. Young people should learn to face the future out of the past; they should be equipped with a sensitivity for conservatism as well as progression, shaped and directed by the Holy Word of God. 


\subsubsection{National education - its function}

In order to realize the abovementioned national ideals the schools will have to co-operate, pupils will have to be encouraged to join youth organiza= tions which identify themselves with all the Christian and the national ideals. By means of words and deeds teachers should guide and assist their pupils to the achievement of a Christian national feeling and, in doing so, destroy all traces of chauvenism and a feeling of unconcern with the matter of national identity. What is im= portant is the teacher's efforts to take his pupils along with him (not to push them ahead), his efforts to inspire them to enthusiasm (not to reproach or indoctrinate them). Pushing them along, reproac= hing or indoctrinating them automatically cause his pupils to detest the (national) ideals which the teacher ever hoped to achieve.

Symbols such as the national flag, the national anthem and so forth should receive a prominent and significant place in all school activities, but then again, such activities should never be forced on the pupils. Pride in their national symbols should be brought home to pupils by persuasion, and not by force.

\section{In conclusion}

We are at present living in a time in which every= thing which is absurd is glorified - and of this every teacher should be aware. On the other hand, if God is ignored in any aspect of life, all sense disappears in that area of man's existence. The teacher who insists on teaching facts merely for the sake of the facts themselves, and choses not to recognize any other aim apart from teaching facts only, who elects to ignore all the perspec= tives of the Holy Word of God promotes this sen= sation of absurdity which has already conquered so many people's hearts. Neutral education enhances this feeling that there is no God at work in the present world. If emphasis in school is placed merely on neutral experience, if mere knowledge becomes of paramount importance, this attitude of 
God-less horizontalism is strengthened. In our own time, more than ever, it has become essential to practise Christian science and to teach accor= ding to Christian principles. The present time is marked by spectacular scientific and technological advancement, and this fact underlines the unques= tionable necessity of a close alliance of the gos= pel of Jesus Christ with science and technology. In this way only can horisontalism and secularism be combatted. If in education God and the per= spectives supplied by His Holy Word are ignored so that God is limited to a small province of reli= gious feeling or emotion, He is indeed "dead" as far as education is concerned. If He is regarded merely as a solver of problems hitherto unsolved, or as our saviour in times of distress, He will obviously be seen as a God who has to retreat in the face of scientific advancement. It can hardly be otherwise, because as science succeeds in sol= ving more and more problems the necessity of a God who explains those problems disappears.

The Christian rejects such a view of God and in= sists that God is with him in his scientific achievements, and with him in his job of teaching pupils in school.

If pupils are taught to be sensitive for signs and traces of the government of Jesus Christ in this world as well as in his own life all absurdity or horizontalism will disappear. His life will attain sense again; God wil be seen by him as a Devine Power at work in this world. The teacher should also bear in mind that at the end of time it will be asked of him how much he and the children that were entrusted to him succeeded in proclaiming the Kingdom of God in this world.

The Christian teacher has an influence on the child whom he teaches, because he presents himself in his act of teaching and not only facts to be learned. His example is followed by his pupils: fairness, honourableness, industriousness, his sympathetic attitude and consistence inspire his pupils to sus= tained effort. His Christian view of and subordi= nation to authority induces the pupil to do like= wise. Above all, his constant faith because of 
which everything he does is illuminated by the Holy Word of God leads his pupils to a voluntary submis= sion to the authority of Jesus Christ. The Christ= ian teacher sees light because of the light which comes from God (cf Ps 36:10). The Holy Word of God lights his way (Ps $119: 105$ ) in life, and he recei= ves wisdom because he fears and acknowledges God (Prov $1: 7$ ).

\author{
$\mathrm{J} H$ van Wyk \\ PU for CHE
}

(This is a condensed and revised version of an arti= cle written by the late Prof Dr Jan $H$ van Wyk, attached to the Department of Philosophy of Educa= tion, PU for CHE during the last number of years of his life. J L $v d W$ ) 